\title{
Demodex folliculorum, hársekkjamítill, dulin orsök hvarmabólgu
}

Sigurlaug Gunnarsdóttir ${ }^{1}$ hjúkrunarfræðingur, Árni Kristmundsson² sníkjudýrafræðingur, Mark A. Freeman²,3 sníkjudýrafræðingur, Ólafur Már Björnsson ${ }^{1}$ æknir, Gunnar Már Zoëga ${ }^{1,4}$ læknir

\section{ÁGRIP}

Vanstarfsemi i fitukirtlum augnloka er algeng ástæða augnpurrks. Demodex-mítlar geta valdið slíkri vanstarfsemi og par með hvarmabólgu með kláða, purrki og almennri vanlíðan á augnsvæði. Pað er mikilvægt að̋ hafa Demodex-mítla í huga við greiningu hvarmabólgu og ef hefðbundin meðferðarúrræði við hvarmabólgu bregðast. Tveir einstaklingar höfðu árangurslaust fengið hefðbundna meðferð við hvarmabólgu og augnburrki en greindust síðan með hársekkjamítla. Meðferð með BlephEx og Tea tree olíu gaf góða raun. Petta er í fyrsta sinn sem hársekkjamítillinn Demodex folliculorum er greindur hérlendis með erfðafræðilegri tegundagreiningu.
'Sjónlag augnlæknastöð

og Táralind,

${ }^{2}$ Tilraunastöð Háskóla

Íslands í meinafræði, Keldum,

${ }^{3}$ Ross-spítala í dýrafræði, St. Kitts í Vestur-Indíum, ${ }^{4}$ augndeild Landspítala.

Fyrirspurnir: Sigurlaug Guðrún Gunnarsdóttir sigurlaug@sjonlag.is

Höfundar fengu sampykki sjúklinganna fyrir pessari umfjöllun og birtingu.

Greinin barst 26. janúar 2016, sambykkt til birtingar

10. mars 2016.
Augnpurrkur er algengt vandamál og hafa rannsóknir sýnt að sjúkdómurinn hrjáir 5-30\% fólks yfir fimmtugt. ${ }^{1}$ Orsakir augnpurrks eru fjölpættar en pær tvær helstu eru (i) skert framleiðsla tára (aqueous deficient) og (ii) óstöðug tárafilma (evaporative), sem oftast má rekja til hvarmabólgu. Algengasta ástæða hennar er vanstarfsemi í fitukirtlum hvarmanna (meibomian gland dysfunction). Pá hafa umhverfispættir eins og loftraki, einnig veruleg áhrif og í mörgum tilfellum er pó um að ræða sambland allra pessara pátta. ${ }^{1}$

Augnpurrkur leiðir til breytinga í samsetningu tárafilmu augans sem og á yfirborði pess og eru megineinkennin almenn ópægindi á augnsvæði, sjóntruflanir, sviði og aðskotahlutstilfinning í augum. Hefðbundnar meðferðir við augnpurrki eru gervitár, tappar í táragöng, ofnæmistöflur og dropar, doxýcýklín um munn, steradropar og cýklósporín-augndropar. Í einstaka tilfellum dugar pessi meðferð ekki.

Hér á eftir er lýst tilfellum tveggja einstaklinga sem leituðu sér lækninga vegna augnpurrks par sem hefðbundnum meðferðum var beitt án árangurs. Í kjölfarið vaknaði áhugi á að kanna hvort rekja mætti orsökina til Demodex-mítla. Greinarhöfundum er ekki kunnugt um að slíkum tilfellum með tegundagreiningu mítils hafi verið lýst hérlendis fyrr.

\section{Sjúkrasaga}

Tilfelli 1: 72 ára karlmaður með hvarmabólgu og prálátan kláða í augum en að öðru leyti heilsuhraustur. Var lyfjalaus en notaði gervitár (Thealoz) tvisvar til prisvar sinnum á dag í bæði augu. Maðurinn kvartaði yfir táraflæði, aðskotahlutstilfinningu og kláða í augum prátt fyrir notkun gervitára.

Í upphafi hefðbundinnar meðferðar var sjúklingur beðinn um að svara spurningalista, OSDI (Ocular Surface Disease Index), sem gefur til kynna hversu mikil augnópægindin eru (hærri gildi gefa til kynna aukin ópægindi í augum). Niðurstöður listans gáfu til kynna fremur lítil ópægindi prátt fyrir kvartanir. Við skoðun komu í ljós vanvirkir fitukirtlar og purrkur á hornhimnu (sjá dálk T1 í töflu I). Einnig voru hrúður á augnhárum beggja vegna sjáanleg.

Hefðbundin meðferð stóð yfir í 8 mánuði og var á peim tíma ýmsum úrræðum beitt, svo sem augndropum með dexametasóni og tóbramýsíni (Maxidex og Tobradex), hydrokortisón-augndreifu (Hydrocortison med Terramycin og Polymyxin B), chloramphenicolum-augnsmyrsli og doxýcýkíni í töfluformi. Pá var ítrekuð nauðsyn pess að prífa augnhár og nota heita bakstra á augnlok kvölds og morgna.

Að hefðbundinni meðferð lokinni (sjá dálk T2 í töflu I) kvartaði sjúklingurinn enn undan kláđa og purrki í augum. Sjáanlegt hrúður var enn á augnhárum prátt fyrir ítrekuð prif.

Tilfelli 2: 35 ára heilsuhraustur og lyfjalaus karlmaður með prálátan kláða og augnpurrk sem staðið hafði í mörg ár. Hvarmabólga var pekkt síðan 2009 og notaði hann gervitár (Thealoz) prisvar til sjö sinnum á dag pess vegna.

Fyrir hefðbundna meðferð (sjá dálk T1 í töflu I) gáfu niðurstöður OSDI til kynna mikil ópægindi í augum. Við skoðun sást vanstarfsemi fitukirtla og einnig sjáanlegt hrúður á augnhárum beggja augna.

Meðferð hófst með doxýcýklíni í töfluformi og augndropum með dexametasóni og tóbramýsíni (Tobradex). Hann fékk einnig tappa í bæði neðri táragöng, fyrirmæli um að prífa augnhár og notkun heitra bakstra á augnlok kvölds og morgna.

Eftir 5 mánuði kvartaði sjúklingur enn yfir augnpurrki og kláða í kringum augun (sjá nánar T2 í töflu I). Hrúður var enn til staðar á augnhárum prátt fyrir ítrekuð prif. 
Tafla I. Matskvarðar fyrir og eftir mítlameðferð.

\begin{tabular}{|c|c|c|c|c|c|c|c|c|c|c|c|}
\hline Tilfelli & Matskvarðar & & & & & & & & & & \\
\hline & & $\mathrm{T} 1$ & & $\mathrm{~T} 2$ & T3 & & $\mathrm{T} 4$ & & T5 & & T6 \\
\hline & Meðferð & & $\mathrm{H}$ & & & $\pi$ & & $\mathrm{C}$ & & $\mathrm{TT}$ & \\
\hline \multirow{7}{*}{$\begin{array}{c}1: \\
72 \text { ára kk }\end{array}$} & & & & & & & & & & & \\
\hline & OSDI & 8,3 & & 12,5 & - & & 6,25 & & 5,5 & & 6,25 \\
\hline & MGD & $6 / 5$ & & 8 o.u. & - & & 8 o.u. & & 4 o.u. & & 8 o.u. \\
\hline & BUT & $8 / 10$ & & $8 / 5$ & - & & $6 / 10$ & & 7 o.u. & & $>10$ o.u. \\
\hline & SPK & ++ o.u. & & 0 o.u. & - & & 0 o.u. & & $+o . u$. & & $+0 . u$ \\
\hline & Schirmer & $14 / 22^{1}$ & & & - & & & & & & \\
\hline & Fjöldi mítla ${ }^{2}$ & & & & 4-6 o.u. & & 3 o.u. & & 3-5 o.u. & & 1-2 o.u. \\
\hline \multirow{7}{*}{$\begin{array}{c}\text { 2: } \\
35 \text { ára kk }\end{array}$} & & & & & & & & & & & \\
\hline & OSDI & 37,5 & & 22,9 & - & & 10,4 & & 16,6 & & 10,4 \\
\hline & MGD & $8 / 3$ & & $8 / 6$ & - & & $8 / 7$ & & 8 o.u. & & 8 o.u. \\
\hline & BUT & $>10$ o.u. & & $>10$ o.u. & - & & $>10$ o.u. & & $>10$ o.u. & & $>10$ \\
\hline & SPK & ++ o.u. & & +o.u. & - & & $0 /+$ & & 0 o.u. & & 0 o.u. \\
\hline & Schirmer & $12 / 16$ & & & - & & & & & & \\
\hline & Fjöldi mítla² & & & & 4-6 o.u. & & 3 o.u. & & 3-4 o.u & & 1-2 o.u. \\
\hline
\end{tabular}

T1: Hefðbundin meðferð hefst; T2: Hefðbundinni meðferð lýkur; T3: Mítlameðferð hefst ; T4: tveimur vikum eftir að mítlameðferð hefst; T5: 6 vikum eftir að mítlameðferð hefst; T6: 10 vikum eftir að mítlameðferð hefst.

H: Hefðbundin meðferð; TT: Meðferð með Tea tree-olíu; C: Meðferð með Cliradex.

OSDI -Ocular Surface Disease Index (0-100; hærri gildi gefa til kynna aukin ópægindi í augum)

MGD -Meibomian Gland Dysfunction (fjöldi opinna kirtla, 8 kirtlar eru taldir miðlægt á neðra augnloki)

BUT - tear film Break Up Time ( $\geq 10$ sekúndur telst eðlilegt)

SPK -Superficial Punctate Keratitis (hægra auga / vinstra auga)

Schirmer -Schirmers Type I,

'Schirmers Type II (hægra auga / vinstra auga)

${ }^{2} \mathrm{Fjöldi} \mathrm{mítla} \mathrm{sem} \mathrm{stingast} \mathrm{út} \mathrm{úr} \mathrm{opi} \mathrm{augnhárasekks} \mathrm{meðfram} \mathrm{hverju} \mathrm{augnhári}$

o.u., (oculus uterque) bæði augu

/ - Skilur hægra og vinstra auga.

Par sem hefðbundin meðferð skilaði í hvorugu tilfelli tilætluðum árangri og enn voru sjáanleg hrúður á augnhárum, tók að vakna grunur um hvarmabólgu af völdum Demodex-mítla.

Rannsóknir hafa sýnt að hrúðurmyndun á augnhárum fylgir öllum klínískum tilfellum Demodex-sýkinga en hrúðrið er talið samanstanda af fitu, keratíni og úrgangi frá mítlunum. ${ }^{2}$

Við skoðun á augnhárum í gegnum raufarlampa (stækkun x25) komu í ljós, pegar togað var í augnhárin og peim snúið, litlir, glærir "pinnar“ sem stungust út úr opi augnhárasekkja meðfram sérhverju augnhári. „Pinnarnir“ urðu lengri eftir pví sem snúið var meira, jafnvel svo að peir skildu sig frá augnhárinu. Sýni af augnhárum voru pví tekin og send til rannsóknar á Tilraunastöð Háskóla Íslands í meinafræði að Keldum, par sem pau voru skoðuð með tilliti til mítlasýkingar.

\section{Mitlagreining}

Tilvist Demodex-mítla í sýnunum var rannsökuð með tvennum hætti: (i) Sjónrænni rannsókn, pað er með víðsjár- og smásjárskoðun á sýnum (stækkun x60 - x300); (ii) rannsókn á erfðaefni. Erfðaefnið í sýnunum var einangrað með GeneMATRIX Tissue DNA purification Kit (EURx, Póllandi), samkvæmt leiðbeiningum framleiðanda, en við kjarnsýrumögnun (PCR-próf) var fylgt aðferðafræði Milosevic og fleiri ${ }^{3}$ par sem notaðir voru erfðavísar sem bindast sértækt 16s hluta erfðaefnis hvatbera (16s mtDNA). Afurðir kjarnsýrumögnunar voru sendar til raðgreiningar hjá
First BASE Laboratories Sdn Bhd í Malasíu. BLAST (Nucleotide Basic Local Alignment Search Tool) var keyrt fyrir sérhverja basaröð sem magnaðist upp, til staðfestingar á tegund og próunarfræðilegri stöðu hennar.

Við smásjárskoðun á sýnum greindust mítlar sem samræmdust lýsingum á hársekkjamítlinum Demodex folliculorum (mynd 2). Kjarnsýrumögnun allra sýnanna skilaði 332 basapara afurð sem samkvæmt raðgreiningu og samanburði við pekktar basaraðir reyndist í öllum tilfellum vera Demodex folliculorum. Erfðafræðileg samsvörun við pekktar Demodex folliculorum basaraðir úr erlendum rannsóknum var mikil, eða á bilinu 99,5-100\%. Hins vegar var einungis 79\% samsvörun við Demodex brevis, sem enn hefur óræða próunarfræðilega stöðu ásamt fleiri Demodex-tegundum sem finnast í spendýrum (mynd 3).

\section{Demodex-mítlameðferð}

Í kjölfar niðurstaðna var báðum einstaklingunum boðin meðferð sem beindist gegn Demodex-mítlasýkingum. Áður en meðferð hófst voru teknar ljósmyndir af augnhárum (sjá mynd 1). Skoðuð voru prjú augnhár á hverju auga og talið hversu margir mítlar („pinnar“) stungust út úr opi hvers augnhárasekks (sjá dálk T3 í töflu I). Meðferð hófst með pví að fjarlægja hrúður af augnhárum með rafmagnsbursta (BlephEx - Rysurg, USA).

Báđir einstaklingarnir fengu Tea tree-olíu blautklúta (Tea Tree Cleansing Wipes, The Body Shop) sem nota átti til að prífa 


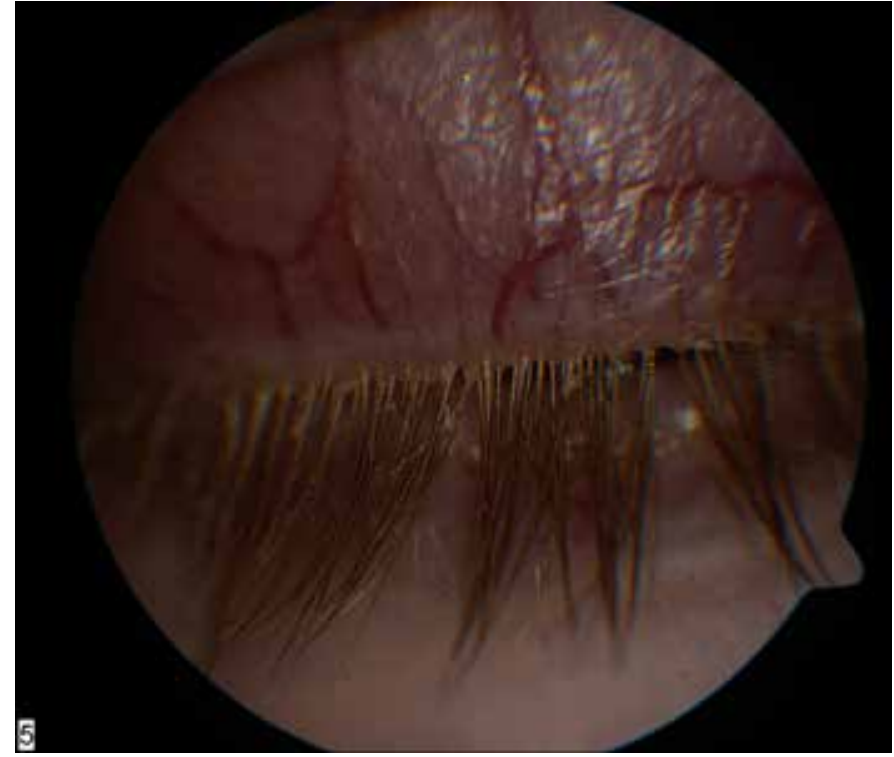

Mynd 1. Tilfelli 2 við fyrstu komu í mítlameðferð. Sívalningslaga hrúður sést við rætur augnháranna.

augnhár, augnabrúnir og andlit kvölds og morgna í tvær vikur. Tea tree-olía inniheldur 4-Terpineol sem drepur Demodex-mítla. ${ }^{4}$ Einnig var peim ráðlagt að auka notkun gervitára eftir pörfum og skola augu ef blautklútur kæmist í snertingu við pau.

\section{Endurkomur}

Tilfelli 1: Að tveimur vikum liðnum (sjá dálk T4 í töflu 1) hafði OSDI lækkað og að sögn sjúklings var „,kláðinn að mestu leyti horfinn“. Enn mátti greina hrúður á augnhárum beggja augna og voru hrúðrin fjarlægð með BlephEx rafmagnsbursta. Par sem engar aukaverkanir virtust fylgja notkun blautklútanna var ákveðið að skipta yfir í blautklúta sem innihalda hærri styrk af 4-Terpineol (Cliradex Bio tissue, Doral, FL 33122, USA) en Tea tree-blautklútarnir. Mælt var með notkun Cliradex-klútana á augnhár, augnabrúnir og andlit kvölds og morgna í fjórar vikur.

Sex vikum frá fyrstu mítlameðferð (sjá dálk T5 í töflu I) kom í ljós að blautklútarnir höfðu verið notaðir tvisvar sinnum á dag í tvær vikur, einu sinni á dag priðju vikuna og síðan hafði notkun peirra verið hætt vegna sviða í húð og í kringum augu. Við skoðun kom í ljós að hrúður á augnhárum beggja augna hafði aukist. Sjúklingur sagðist finna fyrir augnpurrki á morgnana og kláða af og til. Í kjölfar pessara niðurstaðna var ákveðið að skipta aftur yfir í Tea tree-blautklútana og mælt með notkun peirra kvölds og morgna í fjórar vikur. Einnig var veitt viðbótarmeðferð með doxýcýklíni í töfluformi og dexametasón-augndropum í einn mánuð.

Tíu vikum eftir fyrstu mítlameðferð var líðan í augum góð að sögn sjúklings og kláðinn horfinn. Augnhár voru hrein, ekkert sjáanlegt hrúður. Niðurstöður mítlatalningar (sjá dálk T6 í töflu I) bentu til fækkunar á mítlum. Mælt var með áframhaldandi notkun gervitára án rotvarnaefna eftir pörfum og notkun Tea tree-olíu blautklúta kvölds og morgna.

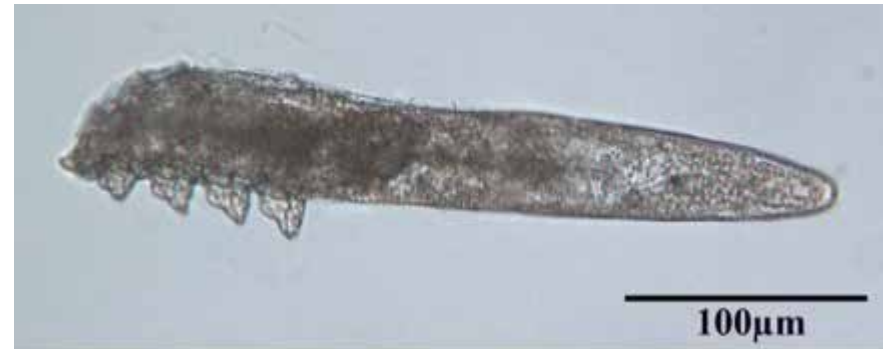

Mynd 2. Hársekkjamítillinn Demodex folliculorum úr íslenskum sjúklingi með hvarmabólgu.

Tilfelli 2: Tveimur vikum seinna var kláðinn farinn og samkvæmt sjúklingi hafði honum ekki liðið svona vel í augunum lengi. OSDI studdi frásögn sjúklings um betri líðan (sjá T4 í töflu I) og par að auki hafði hann minnkað notkun gervitára niður í einu sinni á dag. Smávægileg hrúðurmyndun greindist á augnhárum á vinstra auga svo ný BlephEx hreinsun var gerð á pví auga. Engar aukaverkanir voru af Tea tree-klútunum svo ákveðið var að skipta yfir í Cliradex-klúta sem áttu að notast í fjórar vikur, kvölds og morgna, á augnhár, augnabrúnir og andlit.

Fjórum vikum síðar (sex vikum frá fyrstu mítlameðferð, sjá dálk T5 í töflu I) kom í ljós að notkun blautklútanna hafði verið lítil vegna sviða í andliti og kringum augu sem fylgdi notkun peirra. Sjúklingur lýsti verri líðan í augum og hafði aukið notkun gervitára upp í prisvar á dag. Aukning var á hrúðri í kringum augnhár á báðum augum. Bæði augu voru hreinsuð með BlephEx og áframhaldandi meðferð með Tea tree-klútum, kvölds og morgna í fjórar vikur.

Tíu vikum frá fyrstu mítlameðferð (sjá dálk T6 í töflu I), leið sjúklingnum vel í og umhverfis augun og enginn kláði var til staðar. Augnhár voru hrein (mynd 4) og talning á mítlum benti til fækkunar. Sjúklingurinn var útskrifaður með áframhaldandi notkun gervitára án rotvarnaefna eftir pörfum og notkun Tea tree olíu-blautklúta kvölds og morgna.

\section{Niðurstaða/Umræða}

Demodex folliculorum veldur hvarmabólgu með tilheyrandi einkennum.

Meðferð með Tea tree-olíublautklútum gefur góða raun. Hreinsun augnhára með BlephEx er góð viðbót, par sem erfitt virðist vera fyrir sjúklinga að prífa nægjanlega vel hrúðrið af augnhárum heimafyrir.

Höfundum er ekki kunnugt um neinar fyrri rannsóknir á hvarmabólgu af völdum Demodex-mítla í mönnum á Íslandi.

Algengi mítla eykst með aldri og talið er að $84 \%$ einstaklinga, 60-70 ára, séu með Demodex-mítla en 100\% peirra sem eru 70 ára og eldri. ${ }^{5}$ Fjöldi mítla á hverjum einstaklingi er talinn vera á bilinu 1000 til $2000 .^{2}$

Demodex-mítlar voru fyrst uppgötvaðir af líffærafræðingnum Jacob Henle árið 1841 og ári síðar var fyrstu tegundinni, Demodex folliculorum - hársekkjamítlinum - lýst. ${ }^{6}$ Nú eru pekktar að minnsta kosti 86 tegundir af ættkvísl Demodex, par af tvær, Demodex folliculorum og Demodex brevis, sem finnast á mönnum. ${ }^{7}$ Tegundirnar 


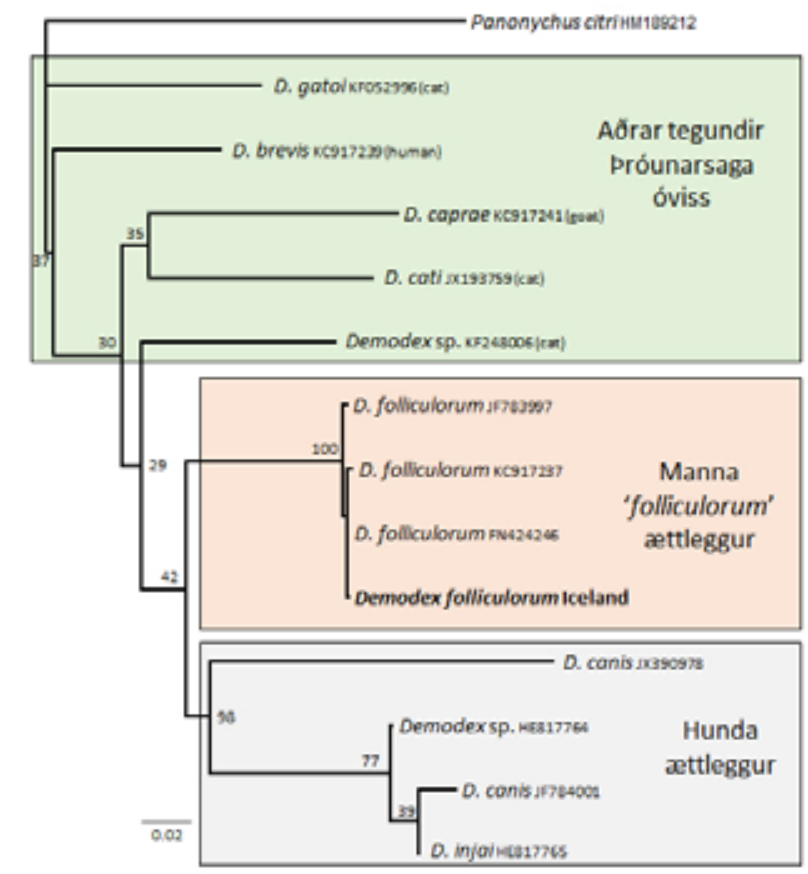

Mynd 3. Próunarfræðileg staða íslenska stofns Demodex folliculorum í samhengi við aðra erlenda stofna sömu tegundar sem og annarra ættleggja Demodex-tegunda, byggt á 16 s mtDNA.

nýta mismunandi vistir, sú fyrrnefnda finnst einkum í augnhárasekkjum, pá oft margir saman, meðan sú síðarnefnda lifir alldjúpt í fitukirtlum (sebaceous glands og meibomian glands) en oftast aðeins stakt dýr. ${ }^{8,9}$

Fullorðnir Demodex folliculorum-mítlar eru um 0,3-0,4mm að lengd en Demodex brevis nokkru styttri, eða um 0,15-0,2mm, og báđar tegundir pví ósýnilegar beru auga. Mítlarnir eru hálfgegnsæir og pinnalaga, með fjögur fótapör á stuttum frambolnum og langan sívalningslaga afturbol. Lífsferill mítlanna er um 15 dagar. Mökun á sér stað efst í hársekkjunum en að henni lokinni færir frjóvgað kvendýrið sig neðar í hársekkinn (D. folliculorum) eða inn í fitukirtill (D. brevis) par sem pað verpir eggjum sínum. Um 12 klukkustundir líða frá mökun og par til varp á sér stað en 60 klukkustundum síðar skríða lirfur úr eggjum. Eftir pað tekur við 6 sólarhringa proskaferli sem samanstendur af nokkrum lirfustigum par til fullproska einstaklingur myndast. Talið er að fullorðin dýr lifi í um pað bil vikutíma. Allt bendir til pess að smit milli manna verði með beinni snertingu par sem mítlarnir lifa stutt utan hýsils síns. ${ }^{6,8,9}$

Demodex folliculorum og Demodex brevis eru almennt taldir vera saklausar samlífislífverur húðarinnar ${ }^{10}$ en við mikinn fjölda peirra (demodicidosis) geta peir orsakað ýmsa húðsjúkdóma og hvarmabólgu. ${ }^{5,6,10}$

Talið er að mítlarnir nærist á útpekjufrumum í hársekkjum og fitukirtlum sem leiði til vanstarfsemi peirra og par með ójafnvægis

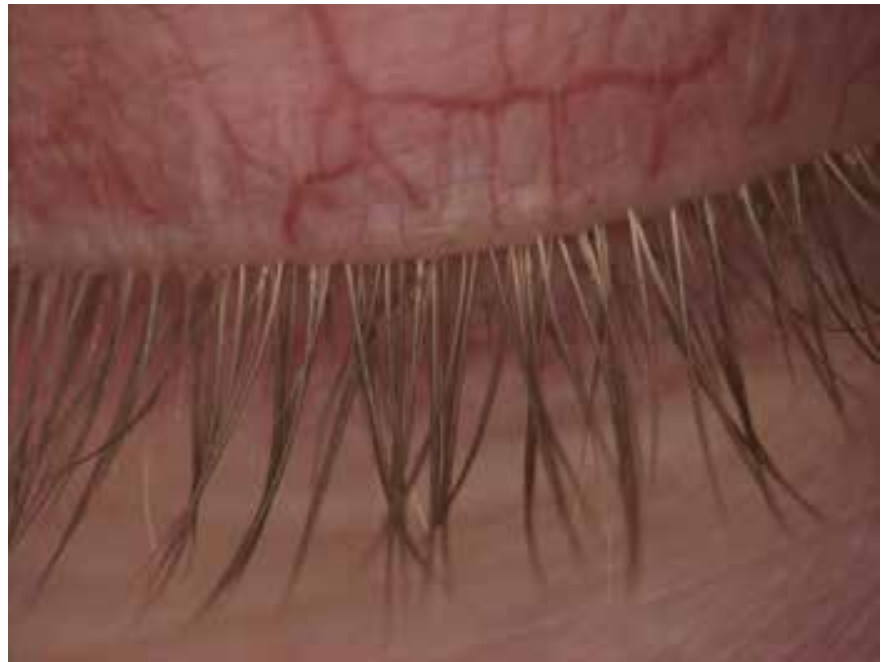

Mynd 4. Tilfelli 2, tíu vikum eftir fyrstu mítlameðferðina.

í fitulagi tárafilmunnar og bólgu á yfirborði augans. Einnig er talið að mítlarnir sjálfir og afurðir peirra virki ónæmiskerfi hýsilsins með tilheyrandi bólgusvörun. ${ }^{11}$ Flestir mítlar drepast inni í augnhárasekkjunum og fitukirtlunum. Par leysast peir upp og skilja eftir sig uppsafnaðan úrgang auk ýmissa baktería sem peir bera með sér. ${ }^{12}$ Rannsóknir hafa sýnt að í táravökva Demodex-hýsla er meira af boðefninu interleukin -17 (IL-17) sem veldur bólgusvörun og stíflu í kirtlum, auk pess að geta valdið skaða á yfirborði augans. Sýnt hefur verið fram á að meðferð með Tea tree-olíu virkar lækkandi á IL-17 gildin sem leiðir til betri líðanar hjá hýsli. ${ }^{13,14}$

Erfitt getur verið að útrýma Demodex-mítlum úr augnhárasekkjum par sem meðferðarheldni skiptir sköpum. ${ }^{14}$ Meðferð miðar pví meira að fækkun mítlanna til að bæta líðan sjúklinga. Ýmsar meðferðir hafa verið reyndar erlendis, einkum ýmiss konar krem sem eiga að sporna við fjölgun mítlanna og Tea tree-olía (4-Terpineol) sem drepur pá. ${ }^{5}$ Rannsóknir hafa einnig sýnt að lyfið Ivermectin, sem notað er við meðhöndlun á ýmsum sníkjudýrum eins og práðormum, sé gagnlegt sem viðbótarmeðferð við Demodex-sýkingum. ${ }^{15}$ Vísbendingar eru einnig um að augnháraburstun með BlephEx sé góð viðbót við aðrar meðferðir. BlephEx prífur vel hrúður af augnhárum og einnig örveruhimnu sem talið er að peki augnhvarma hjá peim sem eru með hvarmabólgu. ${ }^{16}$

Megineinkenni augnpurrks og hvarmabólgu eru aðskotahlutstilfinning, kláði, sviði, útferð á augnhárum, roði í hvörmum og breytileg sjón. Kláði og aðskotahlutstilfinning eru algengustu einkennin við hvarmabólgu vegna Demodex. ${ }^{2}$ Hvarmabólga er algengt vandamál sem oftast svarar hefðbundinni meðferð vel. Skortur á árangri við hefðbundna meðferð er algengasti samnefnari hvarmabólgu af völdum Demodex. Einstaklingar með hvarmabólgu af völdum Demodex hafa margir reynt fjölmörg mismunandi meðferðarúrræði vegna augnpurrks, vanstarfsemi fitukirtlanna og ofnæmis, par með talin gervitár, ofnæmislyf og dropa, doxýcýklín um munn, steradropa og cýklósporín-augndropa.

Við augnskoðun með raufarlampa er mikilvægt að leita eftir „pinnalaga“ fyrirbærum meðfram augnhárum í augnhárasekkj- 
unum og sjást pau best við að minnsta kosti 25x stækkun. ${ }^{5}$ Sívalningslaga hrúður við rót augnháranna (mynd 1) er einkennandi fyrir Demodex-hvarmabólgu. ${ }^{17}$ Mítlarnir dvelja í hársekkjum augnháranna og sjást einungis að litlu leyti utan peirra. Með pví að toga varlega með töng í augnhár og snúa pví eins og skeið væri snúið eftir innra byrði skálar eru mítlarnir hraktir út í op hársekksins og verða pannig sjáanlegir. ${ }^{11,14}$

Pessi tvö tilfelli sýndu bata eftir mítlameðferð og lýstu ákveðnum létti par sem kláði minnkaði til muna eða hvarf. Augnhár litu mun betur út og OSDI-spurningalistinn staðfesti betri líðan. Hvarmabólga af völdum Demodex er vangreind pó tilvist hennar hafi verið pekkt í fjöldamörg ár. Par af leiðandi er mikilvægt að leita eftir Demodex-mítlum pegar hrúður sést á augnhárum og ef hefðbundin meðferð hefur ekki gagnast nægjanlega.

Að lokum má minnast pess sem Coston skrifaði árið 1967:18 "Consider the scrambling of this microscopic octopoded mob while the host sleeps: males seeking, finding, breeding females; gravid females seeking new follicles; inhabitants of follicles sweeping feces outside."

\section{Pakkir}

Dr. Halldór Pálmar Halldórsson, líffræðingur hjá Rannsóknarsetri HÍ á Suðurnesjum, fyrir ráðleggingar vegna sýnatöku og framkvæmd hennar.

\section{Heimildir}

1. 2007 Report of the International Dry Eye WorkShop (DEWS). Ocul Surf 2007; 5: 75-107.

2. Hom MM, Mastrota KM, Schachter SE. Demodex: Clinical cases and diagnostic protocol. Optom Vis Sci 2013; 90: e198-205.

3. Milosevic MA, Frank LA, Brahmbhatt RA, Kania SA. PCR amplification and DNA sequencing of Demodex injai from otic secretions of a dog. Vet Dermatol 2013; 24: 286-e66.

4. Tighe S, Gao YY, Tseng SC. Terpinen-4-ol is the Most Active Ingredient of Tea Tree Oil to Kill Mites. Transl Vis Sci Technol 2013; 2: 2 .

5. Liu J, Sheha H, Tseng SC. Pathogenic role of Demodex mites in blepharitis. Curr Opin Allergy Clin Immunol 2010; 10: 505-10.

6. Rufli T, Mumcuoglu Y. The hair follicle mites Demodex folliculorum and Demodex brevis: biology and medical importance. A review. Dermatologica 1981; 162: 1-11.

7. Desch CE. Human hair follicle mites and forensic acarology. Exp Appl Acarol 2009; 49: 143-6.
8. Rather PA, Hassan I. Human demodex mite: the versatile mite of dermatological importance. Indian J Dermatol 2014; 59: 60-6.

9. Desch C, Nutting WB. Demodex folliculorum (Simon) and D. brevis akbulatova of man: redescription and reevaluation. J Parasitol 1972; 58: 169-77.

10. Elston CA, Elston DM. Demodex mites. Clin Dermatol 2014; 32: 739-43.

11. Mastrota KM. Method to identify Demodex in the eyelash follicle without epilation. Optom Vis Sci 2013; 90: e172-4.

12. Bruenech JT, Haugen I-BK. Tørt øye og parasitten Demodex. Scand J Optometry Vis Sci 2014; 7: 1-8.

13. Kim JT, Lee SH, Chun YS, Kim JC. Tear cytokines and chemokines in patients with Demodex blepharitis. Cytokine 2011; 53: 94-9.

14. Koo H, Kim TH, Kim KW, Wee SW, Chun YS, Kim JC. Ocular surface discomfort and Demodex: effect of tea tree oil eyelid scrub in Demodex blepharitis. J Korean Med Sci 2012; 27: 1574-9.
15. Holzchuh FG, Hida RY, Moscovici BK, Villa Albers MB Santo RM, Kara-Jose N, et al. Clinical treatment of ocular Demodex folliculorum by systemic ivermectin. Am J Ophthalmol 2011; 151: 1030-4 e1.

16. Connor C, Choat C, Narayanan S, Kyser K, Rosenberg B Mulder D. Clinical Effectiveness of Lid Debridement with BlephEx Treatment. Invest Ophthalmol Vis Sci 2015; 56 : 4440.

17. Gao YY, Di Pascuale MA, Li W, Liu DT, Baradaran-Rafii A Elizondo A, et al. High prevalence of Demodex in eyelashes with cylindrical dandruff. Invest Ophthalmol Vis Sci 2005; 46: 3089-94.

18. Coston TO. Demodex folliculorum blepharitis. Trans Am Ophthalmol Soc 1967; 65: 361-92.

\section{ENGLISH SUMMARY}

\section{Demodex folliculorum a hidden cause of blepharitis}

\section{Sigurlaug Gunnarsdóttir ${ }^{1}$, Árni Kristmundsson², Mark A. Freeman ${ }^{2,3}$, Ólafur Már Björnsson', Gunnar Már Zoëga ${ }^{1,4}$}

Meibomian gland dysfunction (MGD) is a common cause of dry eye disease. Demodex mites can cause MGD with symptoms like itching, dryness and general ocular discomfort. It is important to consider infestation with Demodex mites in individuals who are non responsive to traditional MGD treatment but also equally important when cylindrical dandruff is seen at the base of the eye lashes.. We report two individuals who had not responded to ocular and systemic treatment for MGD and were then diagnosed with Demodex mites. Treatment with BlephEx and Tea tree oil was successful. This is the first report on Demodex folliculorum in Iceland where a genetic analysis was done.

${ }^{1}$ Sjónlag Eye Center and Táralind, ${ }^{2}$ The Institute for Experimental Pathology University of Iceland, ${ }^{3}$ Ross University School of Veterinary Medicine, Basseterre, St. Kitts, West Indies. ${ }^{4}$ Department of Ophthalmology, Landspitali University Hospital.

Key words: Demodex, blepharitis, debris, tea tree oil, dry eye.

Correspondence: Sigurlaug Guðrún Gunnarsdóttir sigurlaug@sjonlag.is 